\title{
Evaluation of hospital gardens from the point of landscape design: Bursa city sample
}

\author{
Nilufer Seyidoglu Akdeniz ${ }^{1, *}$, Ceren Dalgıc ${ }^{2}$, Dilan Deniz ${ }^{2}$, Zuhal Kara ${ }^{2}$, Pınar Ozkan ${ }^{2}$ \\ 1)* Landscape Architecture Dept. Faculty of Agriculture, University of Uludag, 16059 Bursa, Turkey \\ ${ }^{2)}$ Landscape Architecture Dept. Institute of Science, University of Uludag, 16059 Bursa, Turkey \\ Corresponding author: nilsem@yahoo.com
}

\begin{abstract}
Hospital gardens, one of the urban public outdoors, are located in the active spots of the city and are important as the image of the city. Hospitals will also be effective in quality of patient health and urban environment with their services. A well-designed hospital garden helps patients to feel good about themselves as well as shorten the healing process. Hospital gardens should be design comfortably according to the needs and desires of the users, create positive effects in physical and spiritual sense and create a social environment by saving both patients and employees from monotony. In this study, a total of 26 private and public hospital gardens in districts of Bursa city center (Osmangazi, Yildirim, Nilufer) were examined in detail. The evaluation of the landscape designs of the hospitals were done by scored method, and the success status were determined by five categories; space use, comfort and image, transportation, equipment and maintenance. As a result, it was identified that the landscape designs were successful with a range of 65-85\% in hospitals in Bursa city center, but some deficiency about designs, especially requirement of renovation and maintenance studies were detected. It was found that State hospitals were more successful than private hospitals. The landscape projects of hospitals should be absolutely needed and it was stated that creating spaces with landscape architects where patients and the staff can use are important.
\end{abstract}

Keywords: Bursa/Turkey, Hospital garden, Landscape design

Özet

Kentsel kamusal dış mekanlardan biri olan hastane bahçeleri kentin etkin noktalarında yer almakta ve kentin imajı olarak önem taşımaktadır. Hastaneler verdikleri hizmetler ile hasta sağlığı ve kentsel çevre kalitesine de etkili olurlar. İyi tasarlanmış bir hastane bahçesi hastaların iyileşme sürecini kısaltmanın yanında ruhsal açıdan kendilerini iyi hissetmelerine de yardımcı olmaktadır. Hastane bahçeleri kullanıcıların istek ve ihtiyaçlarına göre konforlu bir şekilde tasarlanmalı, fiziksel ve ruhsal anlamda olumlu etkiler yaratmalı ve hem hastaları hem de çalışanları monotonluktan kurtararak sosyal bir ortam oluşturmalıdır. Bu çalışmada Bursa kent merkezi ilçelerinde (Osmangazi, Yıldırım, Nilüfer) yer alan toplam 26 adet özel ve kamu hastanelerinin bahçeleri ayrıntılı olarak ele alınmıştır. Hastanelerin peyzaj tasarımlarının değerlendirilmesinde puanlama yöntemi uygulanmış ve alan kullanımı, konfor ve imaj, ulaşım, donatı elemanları ve bakım olmak üzere beş kategoriye ayrılarak başarı durumları değerlendirilmiştir. Sonuç olarak Bursa kent merkezinde yer alan hastanelerin peyzaj tasarımlarının \% 65-85 ile başarılı oldukları belirlenmiş, fakat tasarım açısından eksikliklerin olduğu özellikle yenileme ve bakım çalışmalarının gerekli olduğu tespit edilmiştir. Devlet hastanelerinin peyzaj tasarımı açısından özel hastanelerden daha başarılı olduğu saptanmıştır. Hastanelerin peyzaj projelerinin mutlaka olması gerektiği ve peyzaj mimarları ile birlikte hastaların ve personelin de faydalanabileceği mekanların oluşturulmasının önemli olduğu tespit edilmiştir.

Anahtar Kelimeler: Bursa/Türkiye, Hastane bahçeleri, Peyzaj Tasarımı

\section{Introduction}

According to the World Health Organization (WHO), health is defined as not only the absence of any illness of an individual but also a well-being and satisfaction in physical, mental and social areas. The good quality of environment is important as well as hospitals for the health of individuals and 
societies (Karakaya and Kiper, 2011). Because, hospital gardens are generally stressful environments which negatively affect to people physically and psychologically. Hospital gardens are important in helping people get rid of treatment process caused stress and feel themselves relaxed. These gardens are open spaces where passive or semi-passive activities that ensure the consistency of the urban green texture as the image of the city are carried out (Aksu and Demirel 2012; Sakıc1 and Var, 2013; Sakıc1 et.al. 2013; Sahin et.al. 2016). It is important to create a kind of user friendly design for both indoor and outdoor spaces considering the needs of the patients, visitors and the staff working at hospitals (Gulez et.al. .2001; Ergenoglu and Aytug, 2007). It is important for hospitals, both indoors and outdoors, to provide aesthetic and functional designs that will support both user-friendly design and socialization with taking into account the wishes of patients, visitors and staff (Gulez et al.2001; Ergenoglu and Aytug, 2007; Karakaya and Kiper, 2011). A well-designed hospital yard shall leave a positive impression on patients; allow both the staff and the patients to get away from the clinical environment and provide them with social environment free from monotony (Karakaya and Kiper, 2011. Roger, 2002. Aksu and Demirel, 2012).

Healing effect of the hospital gardens and similar healing facility gardens is a scientifically proven fact today (Ulrich 2002). In order to enhance the healing mission of the hospitals it is necessary to provide a visually satisfying environment besides heading to long lasting designs (Ergenoglu and Aytug, 2007). For this purpose, an attractive area should be created to ensure that the buildings are appropriately located so that the users shall be close to the nature ( $\mathrm{Li}$ and Liu 2016).

The core of the hospital design is to emphasize the return to green ( $\mathrm{Li}$ and Liu 2016) It has been observed that spending some time in natural environment and watching the aesthetic beauties created by natural scenes contribute to people's psychology positively (Kaplan and Kaplan 1989; Adevi and Martesson 2013) and create positive effect on blood pressure, heart activities and muscle strains by reducing stress (Ulrich, 2002; Sakıcı and Var, 2013; Frumkin, 2001; Diette et.al. 2003). Particularly walking around the hospital yard, spending time in sunny and shaded areas, socializing, and finding opportunity to do exercise etc. create a therapeutic environment (Marcus and Barnes,1999). However, the design should be created in a way considering the patients who prefer watching the view through their windows instead of taking the advantage of the yard actively (Ulrich, 1999; Karakaya and Kiper, 2011). Moreover, certain dimensions in the landscape seem easier to reconcile with for people that are psychologically vulnerable. Vistas with large areas covered with grass, which contain some larger trees and water, are generally associated with experiences of protection, peace and quietness (Ulrich, 1999; Adevi and Matersson, 2003).

In this study, the present conditions of public and private hospital gardens in Bursa central districts (Osmangazi, Yildirim and Nilufer) were determined, assessments were made according to the landscape design criteria, and the problems were exhibited and solutions proposals were introduced.

\section{Material and Methods}

\section{Material}

Research material consists of the state and private hospitals located in central districts of Bursa (Osmangazi, Yıldırım and Nilüfer). .Bursa province, the geographic coordinates of which are $39^{\circ} 35^{\prime}-$ $40^{\circ} 40^{\prime}$ north latitudes and $28^{\circ} 10^{\prime}-30^{\circ} 00^{\prime}$ east longitudes, is settled in the Susurluk basin in the south of Marmara Region. Mount Uludağ, which is the most important mountain of the Marmara Region, is also located within the borders of this province. Samanlı Mountains rise in the north and Katırlı and Mudanya Mountains in the south. İnegöl and Yenişehir Plains lie in the east. Although common characteristics of Mediterranean climate can be seen in Bursa, the average temperature of the region is low, total annual rainfall is high and the distribution of the rainfall by month is relatively regular when compared with Mediterranean Region. De Mortanne's drought index indicates the summers to be arid, autumns and springs to be slightly humid. The average annual temperature is $14.4^{\circ} \mathrm{C}$, relative humidity is $68.6 \%$ and rainfall is $691.9 \mathrm{~mm}$. (Figure 1). [15]. Totally 26 hospitals, 10 of which are state and 16 are private ones, have been observed within the scope of the study. Locations of the hospitals are given in Figure 1. 


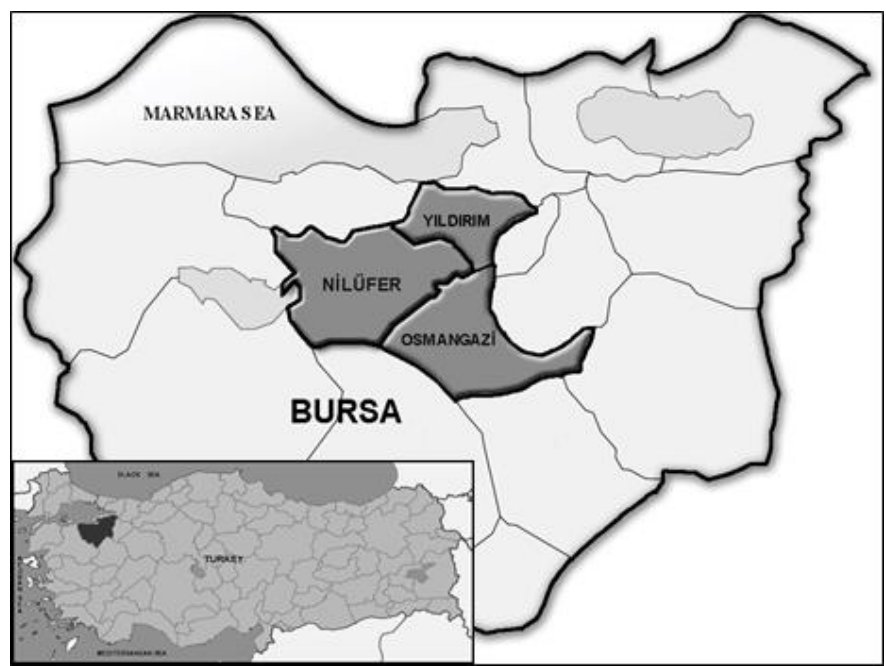

Figure 1. The position of Bursa

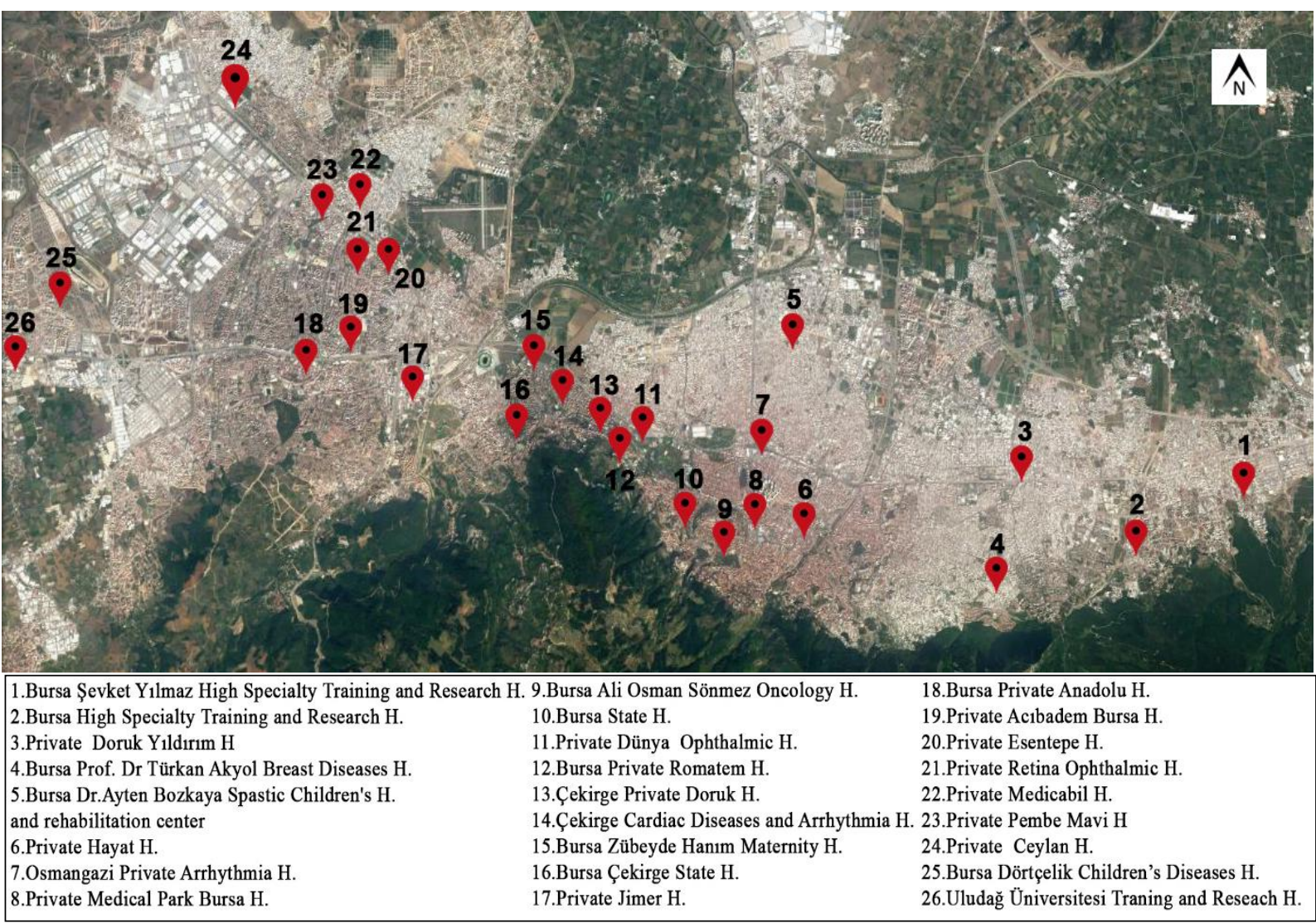

Figure 2. Locations of the hospitals included in the study.

\section{Methods}

In this research, data collection, synthesis and analysis methods were used. The current situation of 26 hospital gardens located in the central districts of Bursa were identified by surveys. It was used scoring method which modified the researches of Karakaya and Kiper (2011), Aksu and Demirel (2012), Sakici et al. (2013). The design criterias of scoring method were divided into five groups: comfort and image, space usage, equipment and maintenance. Then, each group was classified within itself and a total of 25 criteria were determined. The groups used for design criterias and the criterias were as follows: 
1. Comfort and Image (Overall impression on the hospital, Possibility of scenery view, Contribution to the persistence of the urban texture, Plant use)

2. Space Use (Entrance and entrance units joints, Regulations for the disabled, Availability of children playgrounds, Availability of sports facilities, Hospital yard allowing free circulation, Availability of cafe, canteen etc, Element in the garden (hills, ascents, descents etc.)

3. Access (The status of the E.R vehicle path, Sufficiency of parking lots, Detached pedestrian and vehicle paths, Sufficiency in physical access, Availability of guide signs).

4. Reinforcement Elements (Availability of Statues etc., Availability of water elements, Sufficiency of sitting sets, Sufficiency of lightning elements, Sufficiency of waste bins, Sufficiency of warning and guide signs).

5. Maintenance (Maintenance of plant elements, Maintenance of upholstery, Maintenance of sitting elements). The score values which used for evaluation of design criteras were between $0-3$, and determined as not absent ( 0 points), negative ( 1 points),partially positive ( 2 points) and positive ( 3 points). The total points was identified by collection of points in each hospitals and scored based on maximum points. Hospitals were assessed to be at $0-35 \%$ unsuccessful, $35-65 \%$ partially successful, $65-$ $85 \%$ successful, $85-100 \%$ very successful, depending on their success status.

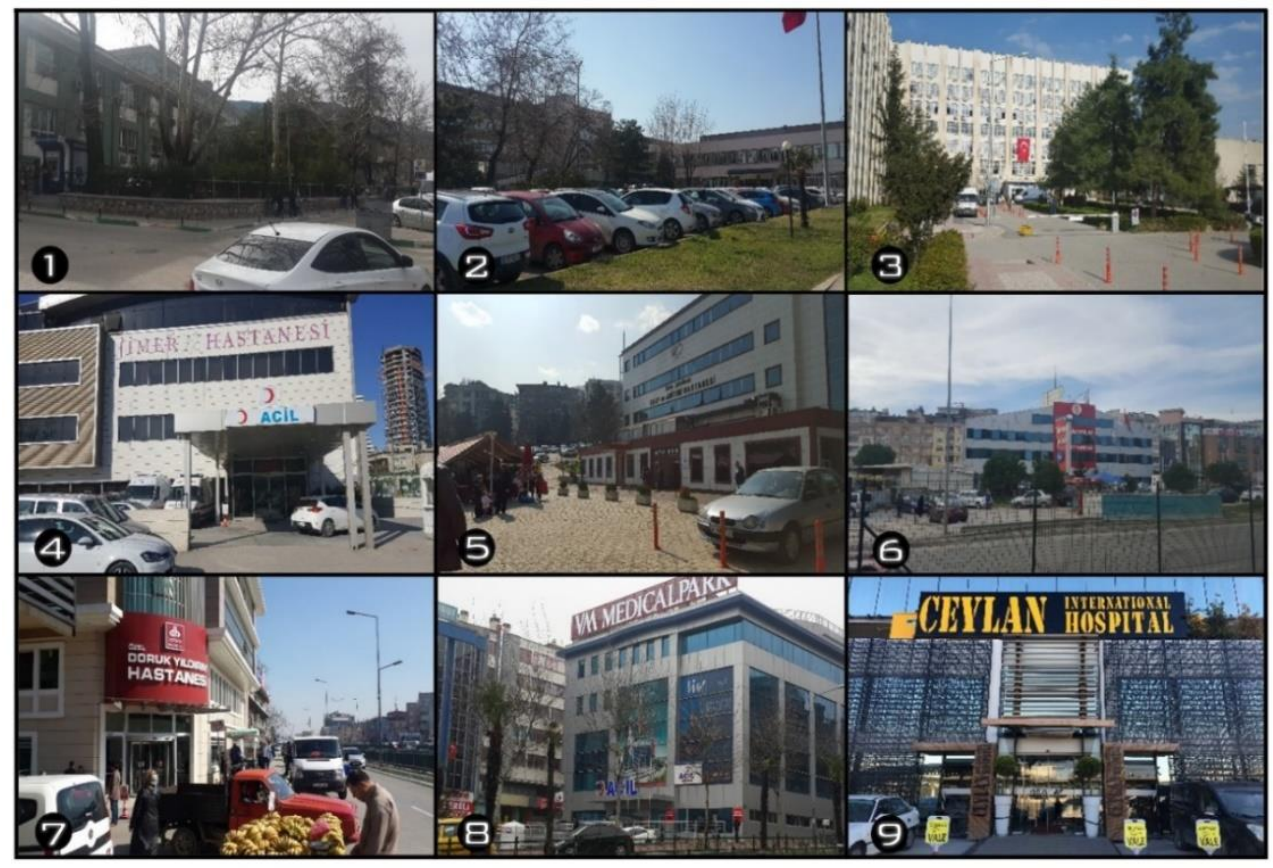

Figure 3. General views of the hospitals (1. Bursa State H., 2. Bursa High Specialty Training and Research H., 3. Uludağ University Training and Research H., 4. Private Jimer H., 5. Çekirge Private Cardiac Diseases and Arrhythmia H., 6. Private Bursa Anadolu H., 7. Private Doruk Yıldırım H., 8. Private Medicalpark H., 9. .Private Ceylan International H.)

\section{Results and Discussion} Nilüfer)

General status of the hospitals located in central districts of Bursa (Osmangazi, Yıldırım,

While evaluating the general status of the hospitals, the presence of hospital gardens and existing plants and the reinforcement elements on these gardens have been considered. It has been concluded that $73.08 \%$ of the hospitals have a yard whereas $26.92 \%$ of them doesn't. Some of the hospitals evaluated within the scope of this study are displayed in figure 2 . Those that do not own a yard are generally private ones. Hayat Hospital, Medicabil Hospital, Medicalpark Hospital, Doruk Yıldırım Hospital are of the private hospitals not having a yard. These mentioned hospitals are generally located in areas with traffic intensity, which are commonly main streets an avenues, and they are surrounded with buildings. 
For all that, it was observed that there were more natural and exotic plant variety in Bursa State Hospital, Private Bursa Romatem Physical Therapy and Rehabilitation Hospital, Yuksek Ihtisas Sevket Yilmaz Hospital, Cekirge State Hospital, U.U. Education and Research Hospital which has own garden. However, the gardens were usually reserved as a car parks, and the use of plants in pots or containers were determined in private hospitals. Samples named Picea orientalis, Pinus nigra, Platanus orientalis for nature species and Cedrus atlantica, Euonymous japonica 'Aurea Variegata', Trachycarpus fortunei, Ligustrum sp., Thuja orientalis, Robinia pseudoacacia, Nerium oleander, Chamaecyparis lawsoniana for exotic species can be given.

Evaluation of the hospitals located in central districts of Bursa (Osmangazi, Yıldırım, Nilüfer) in terms of landscape design.

The scores of the hospitals evaluated according to the scoring method of the study are displayed on Table 1. When the overall impression on the hospitals considered according to Table 1, it will be concluded that state hospitals are scored higher due to having larger usage area, being sufficient in terms of plant use, being located in central points of the city and contributing the persistence of the urban texture. None of the hospitals have sports facilities. Only two hospitals, which are Private Dünyagöz and Dr. Ayten Bozkaya Spastic Children's Hospital, have playgrounds for children. Moreover, all involved hospitals have been found to be inadequately equipped considering the disabled and therefore received low scores. As for the title access, the hospitals within the scope of the study commonly have received high scores since they are located in the most easily accessible points of the city which enables them to be easily accessed by underground, public busses, private cars and even on foot. However, some hospitals have received lower scores since they have emergency accesses shared with the main entranceexit facilities. Bursa State Hospital, Şevket Yılmaz High Specialty Hospital, Uludağ University Training and Research Hospital on the other hand, have multiple entrances and exits besides having emergency access detached from pedestrian entrance, which brings them higher scores. Nearly all hospitals have sufficient parking lots. Some hospitals such as Bursa State Hospital, Şevket Yılmaz High Specialty Hospital, Uludağ University Training and Research Hospital and Çekirge Private Cardiac Diseases and Arrhythmia Hospital have their own parking lots and have received higher scores whereas those located in the city center face parking problems which cause them receive lower scores. When the reinforcement elements such as water, sculptures etc. are considered, all the hospitals fail in using them. Only Bursa State Hospital, Çekirge State Hospital and Şevket Yılmaz High Specialty Hospital have the statute of Atatürk. When lightening elements are considered it can be stated that they have been used in a relatively sufficient way. As for sitting elements, it has been observed that pergola and benches etc. are used in some of the hospital gardens and those hospitals utilizing those kind of sitting sets have received higher scores (Bursa State Hospital, Şevket Yılmaz High Specialty Hospital, Zübeyde Hanım Maternity Hospital, Private Dünyagöz Hospital). On the contrary it has been observed that some hospitals do not utilize any kind of sitting elements in outdoor spaces which causes them receive lower scores. Plant elements and reinforcement elements have been observed to be sufficient in number in state hospitals but they are poorly maintained. When compared with the ones used in state hospitals those in private hospitals have been observed to be maintained in a better way which causes them receive higher scores. When the success scores of the hospitals located in central districts of Bursa, it has been observed that the hospitals are partly successful $(38.46 \%)$. It has also been concluded that the number of the successful and unsuccessful hospitals are the same with the percentage of 30.77. (Figure 4)

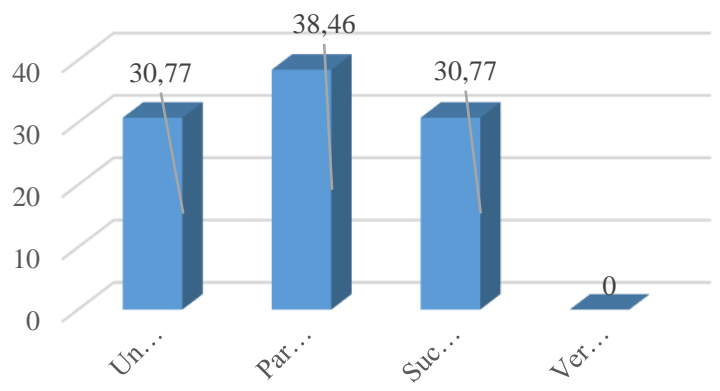

Figure 4. Success scores of the hospitals 
Table 1. Scoring the hospital gardens considering design criteria.

\begin{tabular}{|c|c|c|c|c|c|c|c|c|c|c|c|c|c|c|c|c|c|c|c|c|c|c|c|c|c|c|}
\hline Design Criteria & 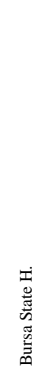 & 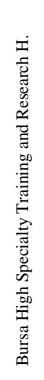 & 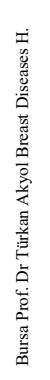 & 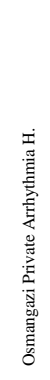 & 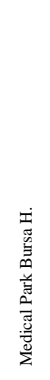 & 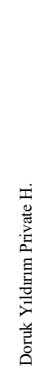 & 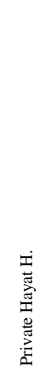 & 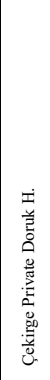 & 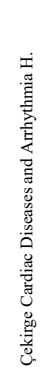 & 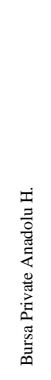 & 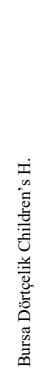 & 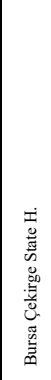 & 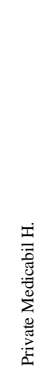 & 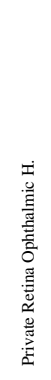 & 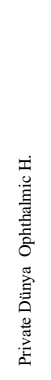 & 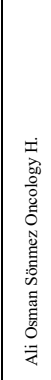 & 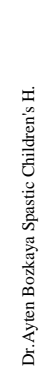 & 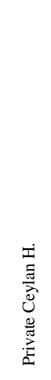 & 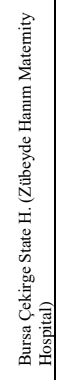 & 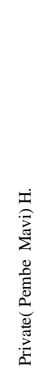 & 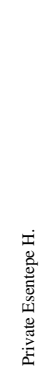 & 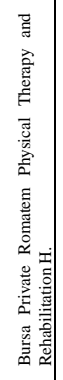 & 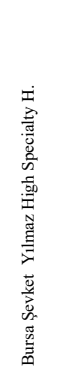 & 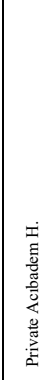 & 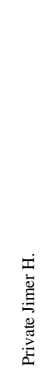 & 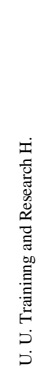 \\
\hline \multicolumn{27}{|l|}{ Comfort and Image } \\
\hline Overall impression on the hospital & 3 & 3 & 3 & 0 & 0 & 0 & 0 & 0 & 2 & 1 & 3 & 3 & 1 & 2 & 2 & 1 & 1 & 1 & 3 & 2 & 2 & 3 & 3 & 2 & 2 & 3 \\
\hline Possibility of scenery view & 3 & 3 & 3 & 0 & 0 & 0 & 0 & 0 & 2 & 1 & 0 & 3 & 0 & 0 & 0 & 0 & 0 & 1 & 2 & 1 & 0 & 2 & 3 & 1 & 0 & 3 \\
\hline Contribution to the persistence of the urban texture & 3 & 3 & 3 & 0 & 0 & 0 & 0 & 0 & 1 & 1 & 1 & 3 & 1 & 1 & 1 & 1 & 1 & 1 & 2 & 0 & 1 & 3 & 3 & 1 & 1 & 3 \\
\hline Plant use & 3 & 3 & 3 & 0 & 0 & 0 & 0 & 0 & 1 & 0 & 2 & 3 & 1 & 1 & 2 & 2 & 2 & 0 & 2 & 1 & 1 & 2 & 3 & 1 & 1 & 3 \\
\hline \multicolumn{27}{|l|}{ Space Use } \\
\hline Entrance and entrance units joints & 3 & 3 & 2 & \begin{tabular}{|l|l}
0 \\
\end{tabular} & 0 & 0 & 0 & 11 & 2 & 3 & 3 & 3 & 1 & 1 & 1 & 2 & 11 & 11 & 2 & 1 & 22 & 3 & 3 & 1 & 22 & 3 \\
\hline Regulations for the disabled & 3 & 3 & 3 & 1 & 2 & 2 & 1 & 0 & 3 & 0 & 0 & 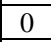 & 1 & 1 & 1 & 1 & 2 & 0 & 1 & 0 & 0 & 3 & 2 & 2 & 0 & 1 \\
\hline Availability of children playgrou & 0 & 0 & 0 & 0 & 0 & 0 & 0 & 0 & 0 & 0 & 0 & 0 & 0 & 0 & 2 & 0 & 2 & 0 & 0 & 0 & 0 & 0 & 0 & 0 & 0 & 0 \\
\hline Availability of sports facilities & 0 & 0 & 0 & 0 & 0 & 0 & 0 & 0 & 0 & 0 & 0 & 0 & 0 & 0 & 0 & 0 & 0 & 0 & 0 & 0 & 0 & 0 & 0 & 0 & 0 & 0 \\
\hline Hospital yard allowing free circulation & 3 & 3 & 3 & 0 & 0 & 0 & 0 & 0 & 2 & 2 & 3 & 3 & 1 & 0 & 1 & 2 & 2 & 0 & 3 & 0 & 0 & 3 & 3 & 3 & 0 & 3 \\
\hline Availability of Cafe, canteen etc. & 3 & 3 & 3 & 0 & 0 & 0 & 0 & 0 & 3 & 3 & 1 & 3 & 0 & 0 & 2 & 1 & 1 & 2 & 3 & 0 & 0 & 2 & 3 & 0 & 0 & 1 \\
\hline Dynamism in the hospital yard (hills, ascents, descents etc.) & 2 & 3 & 3 & 0 & 0 & 0 & 0 & 0 & 0 & 0 & 1 & 3 & 0 & 0 & 1 & 1 & 0 & 0 & 2 & 0 & 0 & 0 & 0 & 0 & 0 & 2 \\
\hline \multicolumn{27}{|l|}{ Access } \\
\hline The status of the E.R vehicle path & 3 & 3 & 3 & 0 & 1 & 1 & 0 & 1 & 2 & 2 & 2 & 3 & 1 & 1 & 1 & 2 & 1 & 1 & 3 & 2 & 2 & 2 & 3 & 3 & 2 & 3 \\
\hline Sufficiency of parking lots & 3 & 3 & 2 & 0 & 2 & 1 & 0 & 0 & 2 & 3 & 3 & 2 & 1 & 2 & 2 & 1 & 1 & 1 & 2 & 3 & 2 & 3 & 3 & 3 & 1 & 3 \\
\hline Detached pedestrian and vehicle paths & 2 & 2 & 2 & 0 & 1 & 0 & 0 & 0 & 2 & 0 & 3 & 3 & 1 & 1 & 1 & 1 & 1 & 0 & 3 & 1 & 1 & 3 & 3 & 3 & 3 & 3 \\
\hline Sufficiency in physical access & 3 & 3 & 3 & 2 & 3 & 3 & 3 & 2 & 3 & 3 & 3 & 3 & 1 & 3 & 1 & 2 & 1 & 2 & 3 & 2 & 3 & 3 & 3 & 3 & 3 & 3 \\
\hline Availability of guide signs & 2 & 3 & 3 & 2 & 3 & 3 & 0 & 0 & 3 & 3 & 3 & 3 & 1 & 2 & 1 & 1 & 1 & 1 & 3 & 2 & 2 & 3 & 3 & 3 & 3 & 3 \\
\hline \multicolumn{27}{|l|}{ Reinforcement Elements } \\
\hline Availability of Statues etc. & 2 & 0 & 0 & 0 & 0 & 0 & 0 & 0 & 0 & 0 & 0 & 2 & 0 & 0 & 0 & 0 & 0 & 0 & 0 & 0 & 0 & 0 & 1 & 0 & 0 & 0 \\
\hline Availability of water elements & 0 & 0 & 0 & 0 & 0 & 0 & 0 & 0 & 0 & 0 & 0 & 0 & 0 & 0 & 0 & 0 & 0 & 0 & 0 & 0 & 0 & 0 & 0 & 0 & 0 & 0 \\
\hline Sufficiency of sitting sets & 3 & 2 & 2 & 0 & 0 & 0 & 0 & 0 & 2 & 0 & 1 & 3 & 1 & 1 & 2 & 2 & 2 & 0 & 3 & 1 & 1 & 2 & 3 & 2 & 1 & 3 \\
\hline Sufficiency of lightning elements & 2 & 2 & 2 & \begin{tabular}{|l|l|l}
0 \\
\end{tabular} & 2 & 2 & 0 & 2 & 3 & 1 & 3 & 3 & 1 & 3 & 1 & 2 & 2 & 0 & 3 & 3 & 2 & 3 & 3 & 3 & 3 & 3 \\
\hline Sufficiency of waste bins & 3 & 3 & 2 & 0 & 1 & 1 & 0 & 1 & 2 & 0 & 1 & 3 & 0 & 1 & 1 & 2 & 2 & 0 & 3 & 3 & 1 & 2 & 3 & 3 & 1 & 3 \\
\hline Sufficiency of warning and guide & 3 & 3 & 3 & 1 & 3 & 2 & 1 & 4 & 3 & 0 & 2 & 3 & 1 & 2 & 1 & 1 & 2 & 1 & 3 & 2 & 3 & 3 & 3 & 3 & 3 & 3 \\
\hline \multicolumn{27}{|l|}{ Maintenance } \\
\hline Maintenance of plant elements & 3 & 3 & 3 & 0 & 0 & 0 & 0 & 0 & 0 & 0 & 2 & 2 & 1 & 1 & 1 & 1 & 1 & 0 & 2 & 2 & 2 & 2 & 1 & 3 & 1 & 3 \\
\hline Maintenance of upholstery & 3 & 1 & 3 & 1 & 1 & 2 & 0 & 0 & 0 & 0 & 3 & 2 & 1 & 2 & 2 & 1 & 1 & 1 & 2 & 3 & 2 & 2 & 2 & 3 & 2 & 2 \\
\hline Maintenance of sitting elements & 3 & 3 & 3 & 0 & 0 & 0 & 0 & 0 & 1 & 0 & 1 & 3 & 1 & 1 & 2 & 1 & 2 & 0 & 2 & 3 & 0 & 2 & 2 & 3 & 2 & 3 \\
\hline
\end{tabular}


When the success score is evaluated regarding each hospital, Bursa State Hospital leads with 61 points $(81.33 \%)$. Bursa High Specialty Training and Research Hospital and Çekirge State Hospital share the second rank with 59 and 58 points $(78.66 \%$ and $77.33 \%)$. Private Hayat Hospital with 5 points $(6.66 \%)$ and Osmangazi Private Arrhythmia Hospital with 7 points $(9.33 \%)$ have been stated as the most unsuccessful hospitals (Table 2)

Table 2. Score ranks of the hospitals.

\begin{tabular}{|c|c|c|c|c|c|c|c|}
\hline Hospital Name & $\begin{array}{l}\text { Comfor } \\
\mathrm{t} \text { and } \\
\text { Image }\end{array}$ & $\begin{array}{l}\text { Space } \\
\text { Use }\end{array}$ & $\begin{array}{l}\text { Acces } \\
\mathrm{s}\end{array}$ & $\begin{array}{l}\text { Reinforcemen } \\
\text { t elements }\end{array}$ & $\begin{array}{l}\text { Maintenan } \\
\text { ce }\end{array}$ & $\begin{array}{l}\text { Total } \\
\text { Score }\end{array}$ & $\begin{array}{l}\text { Success } \\
\text { Rate } \\
(\%)\end{array}$ \\
\hline Bursa State $\mathrm{H}$. & 12 & 14 & 13 & 13 & 9 & 61 & 81.33 \\
\hline $\begin{array}{l}\text { Bursa High Speciality Traning } \\
\text { and Research H. }\end{array}$ & 12 & 15 & 14 & 10 & 7 & 58 & 77.33 \\
\hline $\begin{array}{l}\text { Bursa Prof .Dr Türkan Akyol } \\
\text { Breast Diseases H. }\end{array}$ & 12 & 14 & 13 & 9 & 9 & 57 & 76.00 \\
\hline $\begin{array}{l}\text { Osmangazı Private Arrhythmia } \\
\mathrm{H} \text {. }\end{array}$ & 0 & 1 & 4 & 1 & 1 & 7 & 9.33 \\
\hline Private Medical Park Bursa H. & 0 & 2 & 10 & 6 & 1 & 19 & 25.33 \\
\hline Private Doruk Yıldırım H. & 0 & 2 & 8 & 5 & 2 & 17 & 22.66 \\
\hline Private Hayat $\mathrm{H}$. & 0 & 1 & 3 & 1 & 0 & 5 & 6.66 \\
\hline Çekirge Private Doruk H. & 0 & 1 & 3 & 4 & 0 & 8 & 10.66 \\
\hline $\begin{array}{l}\text { Çekirge Cardiac Diseases and } \\
\text { Arrhythmia H.. }\end{array}$ & 6 & 10 & 12 & 10 & 1 & 39 & 52.00 \\
\hline Private Bursa Anadolu H. & 3 & 8 & 11 & 1 & 0 & 23 & 30.66 \\
\hline $\begin{array}{l}\text { Bursa Dörtçelik Children's } \\
\text { Diseases H. }\end{array}$ & 6 & 8 & 14 & 7 & 6 & 41 & 54.66 \\
\hline Çekirge State H. & 12 & 12 & 14 & 14 & 7 & 59 & 78.66 \\
\hline Private Medicabil H. & 3 & 3 & 5 & 3 & 3 & 17 & 22.66 \\
\hline Private Retina Ophthalmic H. & 4 & 2 & 9 & 8 & 4 & 27 & 36.00 \\
\hline Private Dünya Ophthalmic H. & 5 & 8 & 6 & 5 & 5 & 29 & 38.66 \\
\hline $\begin{array}{l}\text { Ali Osman Sönmez Oncology } \\
\text { H. }\end{array}$ & 4 & 7 & 7 & 7 & 3 & 28 & 37.33 \\
\hline $\begin{array}{l}\text { Dr. Ayten Bozkaya Spastic } \\
\text { Children's H. }\end{array}$ & 4 & 8 & 5 & 8 & 4 & 29 & 38.66 \\
\hline Private Ceylan $\mathrm{H}$. & 3 & 3 & 5 & 1 & 1 & 13 & 17.33 \\
\hline $\begin{array}{l}\text { Bursa Çekirge State H. } \\
\text { (Zübeyde Hanım Maternity } \\
\text { Hospital)i) }\end{array}$ & 9 & 11 & 14 & 12 & 6 & 52 & 69.33 \\
\hline Private Pembe Mavi H. & 4 & 1 & 10 & 9 & 8 & 32 & 42.66 \\
\hline Private Esentepe H. & 4 & 2 & 10 & 7 & 4 & 27 & 36.00 \\
\hline $\begin{array}{llr}\text { Bursa } & \text { Private } & \text { Romatem } \\
\text { Physical } & \text { Therapy } & \text { and } \\
\text { Rehabilitation H. } & \end{array}$ & 10 & 11 & 14 & 10 & 6 & 51 & 68.00 \\
\hline $\begin{array}{l}\text { Bursa High Specialty Şevket } \\
\text { Yılmaz H. }\end{array}$ & 12 & 11 & 15 & 13 & 5 & 56 & 74.66 \\
\hline Private Acıbadem $\mathrm{H}$. & 5 & 6 & 15 & 11 & 9 & 46 & 61.33 \\
\hline Private Jimer H. & 4 & 2 & 12 & 8 & 5 & 31 & 41.33 \\
\hline U.Ü. Traning and Reseach H. & 12 & 10 & 15 & 12 & 8 & 57 & 76.00 \\
\hline
\end{tabular}

It has been determined that the private and state hospitals covered in the study are successful and partly successful in terms of landscape design and that some deficiencies exist. It has been defined that particularly private hospitals are either insufficient in hospital gardens or no gardens exist at all. Some of the private hospitals have been found to be located in the most crowded points of the city where the traffic intensity is at its peak with noise and are stuck among the buildings. It has been determined in some of the private hospitals that hospital gardens are being used either as parking lots without any kind of plant use or just canteens are located there. On the other hand, some private hospitals have been observed to try to add some kind of dynamism with the use of potted or container plants. 
As for state hospitals, it has been observed that green space sufficiency is better when compared with the private ones considering hospital yard status. It has been determined that the garden sizes are generally adequate and they allow free circulation. It has also been found that plant type diversity is high but design is not considered and idle parts exist in the hospital gardens. It has been found that largesized trees occupy more space, shrubs and seasonal straws are less common. The research results are in line with other studies. Petros and Georgi (2011) state that people prefer well-designed hospital gardens with plants and landscape affects their psychology positively. On the other hand, Karakaya and Kiper (2011) state that designs utilizing pots can be effective in overcoming firm ground monotony in hospitals with limited space. Marcus and Barnes (1999) state that a combination of large grass areas and flowers shall be good for patients. Furthermore Sakic1 et.al. (2010) suggest hospital gardens be used by the hospital administrations as a part of treatment by being revised and expanded.

State hospitals on the other hand, have been stated to be sufficient in terms of parking lots. However, it has also been stated that road routes to some of these hospitals are inadequate and therefore traffic intensity occurs either in the hospital gardens or in front of the yard entrances. Some of the private hospitals have been observed not to have their own parking lots. Therefore, people use private parking lots around these hospitals. It has been determined that all of the hospitals' regulations for people with disabilities remain limited with ramps. Sitting sets have been found to be in relatively better condition and sufficient in number when compared with those used in private hospitals. Pergolas and benches are scattered in various places of the gardens. . Ergenoglu and Aytuğ (2007) state that the hospital building itself and its surroundings must be easily accessible adequate parking spaces must be found and pedestrian and handicapped access must be resolved.

Moreover, it has been observed that deficiencies in terms of plant elements and reinforcement units exist. It has been indicated that private hospitals pay attention to maintenance in general whereas in state hospitals there exists a kind of inefficacy in terms of maintenance. As a matter of fact, Karakaya and Kiper (2010) emphasize the post-construction continuity and maintenance of outdoor layout of the hospital.

\section{Conclusion}

Hospital gardens are the places where people use from their birth to death and they remind people of the beauties of life by which they affect human psychology. The abundance of the visual values belonging to a hospital where people visit at least once in their lives is the most important factor affecting both human health and urban sustainability positively. In this context, it is clear how important the landscape designs of hospital gardens are.

It has been occured that the landscape designs were successful or partially successful in the researh which conducted in 26 hospital gardens in Bursa city center. The amount of green space in hospital gardens should be increased and appropriate plant designs should be created. State hospitals are in need of renovation and maintenance studies in terms of design. Since the many private hospitals do not have a garden, if the appropriate area is available, use of pots or containers should be used for plant use.

Undefined areas in hospital gardens should be arranged and converted into active spaces to meet the needs and desires of the users. The deficiencies of the reinforcement must be removed, the seating elements and the number of trash cans must be brought to a sufficient level. Parking arrangements should be made in order to allow free circulation within the hospital yard, solutions should be provided which may be suitable for pedestrian, ambulance and vehicle path separation.

In addition, the use of water elements shall be effective in providing visual and sensory relief in both the patients and the staff. It is also necessary to create active spaces such as playgrounds for children, sports facilities for the users. This matter should be taken into account especially in children's hospital where there is no playground for children and a suitable area should be established.

In conclusion, the number of hospitals in Bursa, which is the $4^{\text {th }}$ largest city of Turkey, is increasing day by day in parallel with increasing population density and growing urbanization. With its physical characteristics, it's necessary to improve the quality and outdoors of hospitals continuously 
which contribute the healing period of patients. A garden is need to be think for hospitals and it's a good idea to create effective design by administrations work with a landscape architect together.

\section{References}

Adevi, A.A., Martesson, F. (2001). Stress Rehabilitation Through Garden Therapy: The Garden as a Place in the Recovery From Stress. Urban Forestry \& Urban Greening. 12:230-237.

Akdeniz, N.S., Zencirkiran, M. (2016). Bursa Geophytes and Their Usage Possibilities in Landscape Design. Journal of Agricultural Faculty of Uludag University. Volume 30, Number: Special Issue, 692-702.

Aksu, O.V., Demirel, O. (2012). Landscape Designs in Hospital Gardens: The Example of Trabzon City. Kastamonu Univ. Kournal of Forestry Faculty. 12(2):236-250.

Diette, G.B., Lechtzin, N., Haponik, E., Devrotes, A., Rubin, H.R. (2003). Distraction Therapy With Nature Sights And Sounds Reduces Pain During Flexible Bronchoscopy: A Complementary Approach to Routine Analgesia. Chest, 123 (3): 941-948.

Ergenoglu A.S., Aytug, A. (2007). Examınation Of Changing Paradıgms and Healıng Hospital Concept in Healthcare Facilit1es With Regard to Architectural Design. YTU Arch. Fac .E-Journal 2 (1): 45-63.

Frumkin, H. (2001). Beyond Toxicity: Human Health and the Natural Environment, American Journal of Preventive Medicine, 20(3):234-240

Gulez, S., Oztekin, B., Bekci, B. (2001). Hospital Garden, Emergency Entrance Hard Surface Design: the Case of Emergency Entrance of Faculty of Medicıne at ZKU. Journal of Bartın Faculty of Forestry. 3 (3) :160-173.

Kaplan, R., Kaplan, S. (1989). Experience of Nature: A Psychological Perspective. Cambridge University Press, New York.

Karakaya, B., Kiper, T. (2011). Investigation of Hospital Outer Space Design in Edirne City. Journal of Tekirdag Agricultural Faculty. 8(2): 49-64.

Li, Z., Liu, F. (2016). Research on the Characteristics and Expression of Modern Hospital Design. Man-MachineEnvironment System Engineering. DOI: 10.1007/978-981-10-2323-1_68. Pp. 609-615.

Marcus, C.C., Barnes, M. (1999). Healing Gardens: Therapeutic Benefits and Design Recommendations. John Wiley and Sons, Inc., New York. 624 p.

Petros, A.K., Georgi, J.N. (2011). Landscape Preference Evaluation for Hospital Environmental Design. Journal of Environmental Protection. 2 : 639-647.

Sahin, C.K., Gül, A., Orucu, O.K., Eraslan, S., Akten, S. (2016). Investigation of Design Principles and Users Demand for Hospital Gardens: Case Study of Egirdir-Turkey. British Journal of Pharmaceutical Research. 11(5): $1-9$

Sakıc1, C., Celik, S., Kapucu, O. (2013). Evaluation of landscape designs of hospital gardens in Kastamonu. SDU Faculty of Forestry Journal. $14: 64-73$.

Sakıc1, C., Var, M. (2013). The Determination of Restorative Experiential Qualities and Design Attributes Because of Revealed to Recuperative Effects of Psychiatric Hospital Gardens. Journal of the Faculty of Forestry, Istanbul University 63 (2): 21-32.

Ulrich, R.S. (2002). Health Benefits of garden hospitals. Plants for People. International Exhibiton Floriade. 10 p.

Yucel, G.F. (2013) Hospital Outdoor Landscape Design. Intech. Chapter 15. http://cdn.intechopen.com/pdfs/45442.pdf. Visited on date: 01/11/2016. 